\title{
Penambahan Sari Jeruk Nipis (Citrus aurantifolia) sebagai Acidifier terhadap Profil Lemak Darah pada Ayam Pelung Jantan
}

\author{
(Feeding of Lime (Citrus aurantifolia) Juice as Acidifier on Blood Lipid Profile in Male \\ Pelung Chicken)
}

\author{
Lilik Krismiyanto $^{1 *}$, Nyoman Suthama ${ }^{1}$, Tristiarti $^{1}$ dan Doni Eko Prabowo \\ ${ }^{1}$ Departemen Peternakan, Fakultas Peternakan dan Pertanian Univesitas, Diponegoro Semarang \\ ${ }^{2}$ Prodi Sarjana Peternakan, Fakultas Peternakan dan Pertanian, Univesitas Diponegoro Semarang \\ Penulis Korespondensi : lilikkrismiyanto@gmail.com
}

\begin{abstract}
ABSTRAK
Sari jeruk nipis mengandung asam sitrat dapat digunakan sebagai aditif alami untuk unggas. Penelitian ini bertujuan untuk mengevaluasi pengaruh penambahan sari jeruk nipis dalam ransum terhadap profil lemak darah pada ayam pelung jantan. Ayam pelung jantan sebanyak 64 ekor dengan bobot badan awal 1.084,44 $\pm 210,89 \mathrm{~g}$, digunakan sebagai ternak percobaan. Perlakuan meliputi T0: ransum peternak tanpa sari jeruk nipis, T1: ransum peternak $+1 \%$ sari jeruk nipis, T2: ransum peternak $+2 \%$ sari jeruk nipis, dan T3: ransum peternak $+3 \%$ sari jeruk nipis. Penelitian disusun dalam rancangan acak kelompok dengan 4 perlakuan dan 4 kelompok (masing-masing 4 ekor) berdasarkan bobot badan. Parameter yang diamati meliputi kolesterol, trigliserida, high density lipoprotein (HDL) dan low density lipoprotein (LDL) darah. Data dianalisis ragam dan jika berpengaruh nyata $(p<0,05)$ dilanjutkan uji ganda Duncan. Hasil penelitian menunjukkan bahwa penambahan sari jeruk nipis dalam ransum nyata $(p<0,05)$ menurunkan trigliserida, LDL dan meningkatkan HDL darah, tetapi tidak berpengaruh terhadap kolesterol. Simpulan adalah penambahan $3 \%$ sari jeruk nipis dalam ransum mampu menurunkan trigliserida, LDL dan meningkatkan HDL pada ayam pelung jantan dengan kolesterol darah masih dalam batas normal.
\end{abstract}

Kata kunci : profil lemak darah; sari jeruk nipis; ayam pelung jantan

\section{ABSTRACT}

Lime (Citrus aurantifolia) juice containing citric acid can be used as natural additive for poultry. The purpose of the present research was to evaluate the feeding effect of dietary lime juice inclusion on blood lipid profile in male pelung chicken. Sixty four birdsof male pelung chicken with initial body weight of $1,084.44 \pm 210.89 \mathrm{~g}$, were used as experimental animals. The treatments applied were T0: farmer ration, T1: farmer ration $+1 \%$ lime juice, T2: farmer ration $+2 \%$ lime juice, and T3: farmer ration $+3 \%$ lime 
juice. The present experiment was assigned in a block randomized design with 4 treatments and 4 groups of block (4 birds each) based on body weight. Parameters measured were blood cholesterol, triglyceride, high density lipoprotein (HDL), and low density lipoprotein (LDL). Data were subjected to ANOVA and when the treatment was significant $(\mathrm{p}<0.05)$, it was continued to Duncan test. The results indicated that feeding effect of lime juice significantly $(\mathrm{p}<0.05)$ decreased blood triglyceride, low density lipoprotein (LDL), and increased blood high density lipoprotein (HDL), but no effect on cholesterol. In conclusion, feeding dietary lime juice at $3 \%$ is able to decrease blood triglyceride, LDL and increase HDL in male pelung chickens, with normal cholesterol level.

Keywords : blood lipid profile; lime juice; male pelung chicken

\section{PENDAHULUAN}

Ayam pelung merupakan ayam lokal sumber daya genetik khas daerah Cianjur, Jawa Barat. Ayam pelung jantan mempunyai suara yang merdu dan nyaring sehingga lebih dikenal sebagai ayam hias (fancy). Selain sebagai ternak hobi, juga dapat dimanfaatkan sebagai penghasil daging, karena ukuran tubuh yang besar dan mempunyai daging yang tebal. Hasil penelitian Balai Penelitian Ternak Ciawi (Sudradjad, 2007) menunjukkan bahwa, ayam pelung jantan dapat juga dikembangkan menjadi ayam pedaging atau ayam potong.

Pemeliharaan ayam pelung jantan sebagai penghasil daging, perlu diupayakan agar ayam sehat sehingga produksi dapat maksimal. Kondisi kesehatan ayam dapat dideteksi dari tinggi atau rendahnya kadar kolesterol dan trigliserida darah. Kolesterol selain sebagai indikator kesehatan juga berfungsi dalam pembentukan asam dan garam empedu, sebagai komponen membran sel, prekursor hormon steroid, dan mempertahankan fungsi sel. Garam empedu yang disintesis di dalam hati, berperan dalam penyerapan trigliserida dan vitamin larut lemak dari ransum (Muchtadi et al., 1993). Peningkatan kadar kolesterol dalam produk ternak sebaiknya dihindari karena dapat menyebabkan gangguan kesehatan bagi konsumen, antara lain penyakit seperti atheroclerosis dan hiperlipidemic. Kelebihan kolesterol dalam darah, dapat diatasi dengan menggunakan substansi yang dapat merangsang produksi dan sekresi getah empedu, antara lain asam sitrat.

Jeruk nipis merupakan bahan alami yang mengandung asam sitrat. Pemberian sari jeruk nipis sebagai aditif dalam ransum ayam pelung diharapkan dapat meningkatkan fungsi pencernaan karena sari jeruk nipis mengandung asam sitrat yang dapat menurunkan $\mathrm{pH}$ sehingga memacu aktivitas enzim dalam saluran pencernaan. Pemberian asam sitrat memiliki pengaruh positif antara lain secara langsung sebagai antimikrobia dan secara tak langsung menurunkan $\mathrm{pH}$ pada saluran pencernaan. Jumlah bakteri pathogen yang tidak tahan terhadap suasana $\mathrm{pH}$ rendah dapat dikurangi dan selanjutnya mampu memperbaiki proses pencernaan dan penyerapan nutrien (Ghazalah et al., 2011). Sandi et al. (2012) menyatakan bahwa usus halus memiliki fungsi untuk penyerapan nutrien. Kondisi asam dari digesta yang masuk ke duodenum akan merangsang pankreas mengeluarkan csarian pankreas yang 
berisi garam bicarbonat, dan enzim lipase serta merangsang garam empedu. Lipase pankreas juga akan merangsang produksi dan sekresi getah empedu, sehingga meningkatkan pemanfaatan kolesterol untuk sintesis asam dan garam empedu, akibatnya kadar kolesterol darah menurun. Disisi lain, akibat peningkatan sintesis garam dan asam empedu terjadi pemanfaatan trigliserida yang mengakibatkan kadar trigliserida dalam darah menurun.

Berdasarkan hal tersebut dilakukan penelitian untuk mengkaji pengaruh penambahan sari jeruk nipis sebagai acidifier terhadap kadar kolesterol, trigliserida, high density lipoprotein (HDL), dan low density lipoprotein (LDL) darah pada ayam pelung jantan.

\section{MATERI DAN METODE}

\section{Ayam dan Ransum Penelitian}

Penelitian menggunakan ayam pelung jantan umur 12 minggu dengan rata-rata bobot badan 1.084,44 $\pm 210,89 \mathrm{~g}$ sebanyak 64 ekor, dipelihara selama 6 minggu. Bahan penyusunan ransum peternak meliputi konsentrat CP 521, dedak halus, dan mineral mix yang disusun dengan kandungan protein kasar $14,57 \%$ dan energi metabolis 2.353,91 $\mathrm{kkal} / \mathrm{kg}$. Sari jeruk nipis ditambahkan dalam ransum sesuai dengan masingmasing level. Sari jeruk nipis dituangkan dalam ransum kemudian kedua bahan tersebut dihomogen agar terkonsumsi semua. Sari jeruk nipis diberikan tiap pagi hari setelah ransum tersebut habis terkonsumsi dilanjutkan dengan pemberian ransum tanpa perlakuan. Air minum disediakan ad libitum.

\section{Parameter Penelitian}

Data meliputi kolesterol, trigliserida, high density lipoprotein (HDL) dan low density lipoprotein (LDL) diukur pada minggu enam pemeliharaan. Sampel darah diambil melalui pembuluh darah vena sayap (vena brachialis) dari 1 ekor ayam tiap ulangan pada akhir penelitian. Sampel dimasukkan dalam tabung yang mengandung (EDTA) sebagai anticoagulant, selanjutnya disentrifuse dengan kecepatan $3000 \mathrm{rpm}$ selama 15 menit. Supernatan berupa plasma disimpan pada suhu $-18^{\circ} \mathrm{C}$ sampai dianalisis. Kolesterol darah dianalisis dengan menggunakan metode enzymatic cholesterol high performance CHOD-PAP KIT. Trigliserida (mg/dl) ditentukan dengan menggunakan metode GPO-PAP dengan prosedur sebagai berikut. serum $10 \mu \mathrm{l}$ ditambah 1 $\mathrm{ml}$ reagen, diinkubasi selama 10 menit pada suhu $20-25^{\circ} \mathrm{C}$. Kemudian disentrifuse selama 2 menit dengan kecepatan 10.000 rpm hingga terbentuk supernatan, selanjutnya ditambah reagen warna hingga terjadi perubahan warna yang dapat diukur dengan spektrofometer pada panjang gelombang $500 \mathrm{~nm}$.

\section{Rancangan Percobaan}

Penelitian menggunakan rancangan acak kelompok dengan 4 perlakuan dan 4 kelompok (masingmasing 4 ekor). Perlakuan yang diterapkan pada penelitian sebagai berikut:

$\mathrm{T} 0=$ ransum peternak tanpa sari jeruk nipis

$\mathrm{T} 1=$ ransum peternak dengan

penambahan $1 \%$ sari jeruk nipis

$\mathrm{T} 2=$ ransum peternak dengan

penambahan $2 \%$ sari jeruk nipis

$\mathrm{T} 3=$ ransum peternak dengan

penambahan $3 \%$ sari jeruk nipis

Data yang diperoleh diolah dengan analisis ragam untuk mengetahui pengaruh perlakuan terhadap peubah yang diukur. Apabila berpengaruh nyata 
dilanjutkan dengan uji Duncan (Gaspersz, 1991).

\section{HASIL DAN PEMBAHASAN}

Hasil penelitian penambahan sari jeruk nipis 0 sampai $3 \%$ terhadap profil lemak darah ayam pelung dapat dilihat pada Tabel 1. Analisis ragam menunjukkan bahwa penambahan sari jeruk nipis berpengaruh nyata $(\mathrm{P}<0,05)$ terhadap kadar low density lipoprotein (LDL), high density lipoprotein (HDL) dan trigliserida darah, tetapi tidak berpengaruh $(\mathrm{P}>0,05) \quad$ terhadap kadar kolesterol darah ayam pelung.

Kadar kolesterol darah pada ayam pelung diberi sari jeruk nipis sampai 3\% menunjukkan nilai yang sama (Tabel 1). Ini berarti bahwa pemberian sari jeruk nipis tidak berpengaruh nyata $(\mathrm{P}>0,05)$ terhadap kadar kolesterol darah. Secara umum kadar kolesterol darah pada penelitian berkisar antara 157,45 - 159,30 $\mathrm{mg} / \mathrm{dl}$, nilai ini masih pada kisaran normal. Menurut Saadah (2003), kadar kolesterol darah unggas yang normal berkisar antara $125-200 \mathrm{mg} / \mathrm{dl}$.

Tabel 1. Profil Lemak Darah Ayam Pelung Jantan

\begin{tabular}{|c|c|c|c|c|}
\hline \multirow[t]{2}{*}{ Parameter } & \multicolumn{4}{|c|}{ Perlakuan } \\
\hline & T0 & $\mathrm{T} 1$ & $\mathrm{~T} 2$ & $\mathrm{~T} 3$ \\
\hline & \multicolumn{4}{|c|}{ - } \\
\hline Kolesterol & 159,30 & 158,16 & 158,80 & 157,45 \\
\hline Trigliserida & $172,43^{\mathrm{a}}$ & $149,10^{\mathrm{b}}$ & $145,97 \mathrm{~b}$ & $119,14^{c}$ \\
\hline HDL & $31,90^{c}$ & $36,92^{b}$ & $37,74^{\mathrm{b}}$ & $42,87^{a}$ \\
\hline LDL & $129,19^{b}$ & $126,27^{a}$ & $110,73^{\mathrm{b}}$ & $113,20^{\mathrm{b}}$ \\
\hline
\end{tabular}

abc Superskrip yang berbeda pada baris yang sama menunjukkan perbedaan yang nyata $(\mathrm{p}<0,05)$.

Penambahan sari jeruk nipis sampai 3\% ransum sebagai acidifier sudah mampu membuat enzim pencernaan bekerja maksimal sehingga dapat meningkatkan kecernaan lemak kasar secara nyata $(\mathrm{P}<0,05)$ pada T2 $\quad(2$ $\mathrm{mL} /$ ekor/hari) dan T3 (3 mL/ekor/hari)
(Mangisah et al., 2016). Namun, peningkatan kecernaan lemak kasar tidak berbanding lurus dengan penurunan kadar kolesterol darah. Hal ini dapat diasumsikan karena hati tidak mampu mengambil kolesterol pada LDL. Fenomena ini sesuai dengan penelitian Abdel-Fattah et al. (2008), bahwa suplementasi asam sitrat sebanyak 1,5 sampai $3 \%$ tidak berpengaruh terhadap kolesterol darah pada ayam broiler. Menurut penelitian Banday et al. (2010), suplementasi asam organik 2 sampai 3\% tidak menunjukkan perbedaan nyata $(\mathrm{P}>0,05)$ terhadap konsentrasi kolesterol darah, dan dikuatkan penelitian sebelumnya (Hernandez et al., 2006), bahwa suplementasi asam organik tidak mempengaruhi metabolit darah ayam broiler.

Penambahan sari jeruk nipis sampai 3\% mampu menurunkan kadar trigliserida darah ayam pelung. Hal ini sejalan dengan kecernaan lemak kasar yang meningkat akibat fungsi air jeruk sebagai acidifier. Data kecernaan lemak kasar berbeda nyata $(\mathrm{P}<0,05)$ meningkat pada pemberian air jeruk nipis 2 dan 3 $\mathrm{ml} /$ ekor/hari (Mangisah et al., 2016). Trigliserida berasal dari absorsi lemak oleh usus halus atau dari hati, diangkut dalam darah sebagai kilomikron dan VLDL. Trigliserida sedikit rendah disebabkan asam lemak banyak diserap atau diangkut dalam bentuk lipoprotein. Harper et al. (1985) menyatakan bahwa, lipid dilepaskan dari jaringan adiposa dalam bentuk asam lemak bebas, dan asam lemak diangkut dalam bentuk lipoprotein. Selain itu, asam lemak juga diangkut dalam bentuk kilomikron dan very low density lipoprotein (VLDL).

Penambahan sari jeruk nipis 3\% mampu meningkatkan HDL dan menurunkan LDL dalam darah. Kadar LDL dalam darah dipengaruhi secara langsung oleh kandungan asam sitrat dalam air jeruk nipis. Pengaruh asam 
sitrat sebagian besar terjadi pada proses pencernaan dan absorsi nutrien di usus halus. Fenomena ini tidak sejalan dengan kolesterol, tetapi secara numerik terjadi penurunan kolesterol. Low Density Lipoprotein (LDL) berperan dalam menyediakan kolesterol dalam jaringan tubuh karena merupakan karier utama untuk kolesterol dari hati ke jaringan tubuh, sehingga kadar dalam darah dipengaruhi oleh konsentrasi kolesterol. Menurut Montgomery et al. (1993) bahwa, peningkatan LDL sejalan dengan peningkatan kadar kolesterol darah, bila kadar kolesterol darah relatif sama maka LDL juga sama, karena LDL berperan dalam penyediaan kolesterol jaringan tubuh. Ganong (1995) menyatakan bahwa LDL merupakan karier utama kolesterol dalam darah dan berperanan penting dalam metabolisme kolesterol. Mekanisme pengambilan LDL dari plasma oleh hati dan jaringan ekstrahepatik dengan perantara reseptor LDL. Sel-sel pada jaringan ekstrahepatik membutuhkan kolesterol untuk membentuk reseptor berupa protein untuk LDL yang muncul dipermukaan membran sel. Low density lipoprotein (LDL) melekat pada reseptor tersebut dan masuk kedalam sel melalui endositosis. Kolesterol kemudian dilepas dalam bentuk bebas untuk digunakan oleh sel (Murray et al., 1999).

Hasil yang sama seperti LDL juga ditemukan pada HDL (Tabel 1) bahwa penambahan air jeruk nipis sampai 3\% menunjukkan hasil yang berbeda. Kadar high density lipoprotein (HDL) dari masing-masing perlakuan berkisar antara 31,90- 42,87 mg/dl. Kadar HDL pada ayam masih berada pada batas normal, seperti yang dilaporkan oleh Saadah (2003), bahwa kadar HDL dalam darah unggas berkisar antara 30-80 mg/dl. High density lipoprotein (HDL) berperan penting dalam transport balik kolesterol dari jaringan ke hati. Kolesterol bebas yang diambil dari jaringan melalui reseptor HDL diubah menjadi ester kolesterol dalam molekul HDL. Lipase hepatik selanjutnya menghidrolisis fosfolipid HDL yang memungkinkan partikel senyawa ini melepaskan muatan ester kolesterolnya ke dalam hati dan menyediakan kolesterol bagi produksi asam empedu (Montgomery et al., 1993 ; Murray et al., 1999). High density lipoprotein (HDL) dalam darah berperan membawa kelebihan kolesterol dari jaringan tubuh kembali ke hati untuk dikatabolisme menjadi asam dan garam empedu yang kemudian masuk dalam usus halus dan dikeluarkan bersama ekskreta (Montgomery et al.,1993).

\section{SIMPULAN}

Berdasarkan hasil penelitian dapat disimpulkan bahwa ransum yang ditambahkan sari jeruk nipis $3 \%$ mampu menurunkan trigliserida dan LDL, meningkatkan HDL pada ayam pelung jantan dengan kolesterol darah masih dalam batas normal.

\section{DAFTAR PUSTAKA}

Abdel-Fattah, S. A., M. H. El-Sanhoury., N. M. El-Mednay, and F. AbdelAzeem. 2008. Thyroid activity, some blood constituents, organs morphology and performance of broiler chicks fed supplemental organic acids. Int. J. Poult. Sci. 7 (3): 215-222.

Banday, T., S. Adil, G. A. Bhat, M. S. Mir and M. Rehman. 2010. Effect of dietary supplementation of organic acids on performance, intestinal histomorphology, and serum biochemistry of broiler chicken. Kashmir University of Agricultural Sciences and Technology of Kashmir, Kashmir.

Ganong, W. F. 1995. Buku Ajar Fisiologi Kedokteran (Review of Medical 
Physiologi). Edisi ke-14. EGC, Jakarta. (Diterjemahkan Oleh Petrus Andrianto).

Gaspersz, V. 1991. Teknik Analisis dalam Penelitian Percobaan. Penerbit Tarsito, Bandung.

Ghazalah, A. A., A. M. Atta, K. Elkloub, M.E.L. Moustafa, Riry and F.H. Shata. 2011. Effect of dietary supplementation of organic acids on performance, nutrients digestibility and health of broiler chicks. Int. J. Poult. Sci. 10 (3): 176-184.

Harper, H. A., V. W. Rodwelldan dan A. Mayes. 1985. Biokimia (Review of Phystological Chemistry). 17 ${ }^{\text {th }}$ Ed. Penerbit Buku Kedokteran EGC, Jakarta (Diterjemahkan oleh Martin Muliawan).

Hernandez, F., V. Garcia, J. Madrid, J. Orengo, P. Catala, and M. D. Megias. 2006. Effect of formic acid on performance, digestibility, intestinal histomorphology and plasma metabolite levels of broiler chickens, Br. Poult. Sci. 47 (1): 50- 56 .

Mangisah, I., B. Sukamto, H. I. Wahyuni, I. Estiningdriati, W. Saputro and L. Krismiyanto. 2016. Nutrient digestibility and performance of male pelung chicken fed rice brand-based ration supplemented with lime (Citrus aurantifolia) juice. Med. Pet. 39(2):119-124.
Muchtadi, D., N. S. Palupi dan M. Astawan. 1993. Metabolisme Zat Gizi. Pustaka Sinar Harapan, Jakarta.

Murray, K. W., D. K. Granner, P. A. Mayes dan V. W. Rodwell. 1999. Biokimia Harper (Harper's Biochemistry). 24 $4^{\text {th }}$ Ed. Penerbit Buku Kedokteran EGC, Jakarta. (Diterjemahkan oleh Andy Hartanto).

Montgomery R., R. L. Dryer, T. W. Conway dan A. A. Spector. 1993. Biokimia Suatu Pendekatan Berorientasi Kasus 2. Edisi ke-1. Gadjah Mada University Press, Yogyakarta (Diterjemahkan oleh M. Ismadi).

Saadah, N. 2003. Kadar Kolesterol Darah Pada Ayam Broiler Yang Diberi Ransum Menggunakan Kunyit dan Temulawak. Fakultas Peternakan, Universitas Diponegoro, Semarang. (Skripsi Sarjana Peternakan).

Sandi, S., R. Palupi dan Amyesti. 2012. Pengaruh penambahan ampas tahu dan dedak padi fermentasi terhadap karkas, usus dan lemak abdomen ayam broiler. Agrinak. 2(1):1-5.

Sudradjad. 2007. Beternak Ayam Pelung. Cetakan ke lima. Kanisius, Yogyakarta. 